\title{
Utilizing nanotechnology and novel materials \& concepts for advanced thermoelectric and thermal management technology development*
}

(C) Takao Mori ${ }^{1,2}$

${ }^{1}$ National Institute for Materials Science (NIMS)

${ }^{2}$ University of Tsukuba

E-mail: MORI.Takao@nims.go.jp

(Получена 12 декабря 2016 г. Принята к печати 19 декабря 2016 г.)

A review is given on some investigations to enhance ZT through very effective selective scattering of phonons from bottom-up nanostructuring methods. Novel concepts are also being utilized in an attempt to overcome the conventional tradeoff in the power factor.

DOI: 10.21883/FTP.2017.07.44662.10

* XV Международная конференция „Термоэлектрики и их применения - 2016“ Санкт-Петербург, 15-16 ноября 2016 г. 